\title{
GEOCHEMICAL AND SEDIMENTOLOGICAL CHARACTERISTICS OF THE LATE QUATERNARY SEDIMENTS OF THE ANAMBRA BASIN
}

\author{
M. E. Okiotor ${ }^{1,}{ }^{*}$, J. E. Ighodaro ${ }^{2}$, E. D. Ogueh ${ }^{3}$ and M. I. E. Nnaji ${ }^{4}$ \\ 1, 2, 3, 4 DEPARTMENT OF GEOLOGY, WESTERn DELTA UNIVERSITY, OGHARA, DELTA STATE, NIGERIA \\ E-mail addresses: ${ }^{1}$ michaelokiotor@gmail.com, ${ }^{2}$ ehikacross@gmail.com, ${ }^{3}$ desireeogueh@gmail.com \\ 4 maxwell.nnaji@yahoo.com
}

\begin{abstract}
Ten samples from sand bars, mouth bars and continental shelf at the Onitsha end of the River Niger were analyzed for their sedimentlogical and geochemical characteristics. The textural analysis carried out on the samples revealed that they ranged from fine to medium grained, moderately to poorly sorted, angular to sub-rounded. The percentage of sand is high compared to that of silt and clay which has a small percentage. Geochemical analysis shows that the samples are high in silica $\left(\mathrm{SiO}_{2}\right)$ content, and due to the poorly sorted nature of the sediments, they were described as immature. The mean grain size ranges from 0.8 to 2.9, which corresponds to coarse-fine grain sands but averagely 2.03 , which is fine grained. Standard deviation ranges from 0.28 to 1.2 , which range from well sorted to poorly sorted but averagely 0.74 , which is moderately sorted. The skewness ranges from -0.34 to 1.13 i.e. strongly coarse skewed to strongly fine skewed but averagely near symmetrical. The kurtosis ranges from 0.42 to 1.25 i.e. very platykurtic to leptokurtic but averagely 1.4 which is leptokurtic. The comparison between the samples(sand bar, mouth and continental shelf sediments) revealed certain distinguishing characteristics; the sand bars are better sorted compared to the continental sediments, they are also of fine grain sands, intensive weathering and texturally more mature compared to the continental shelf sediments, whereas the continental shelf is characterized by poor sorting, medium and coarse grains The mouth bar has similar characteristics with the continental shelf with grain size ranging from fine to coarse grained sands.
\end{abstract}

Key words: Sedimentological, Geochemical, grain size, skewness, kurtosis.

\section{INTRODUCTION}

The Anambra Basin is among the seven sedimentary domains of Nigeria. It is exposed over a roughly triangular territory estimated at $95,000 \mathrm{~km}^{2}$. The Anambra Basin is situated at the South Western extremity of the Benue Trough of Nigeria. It is bounded on the west by the Precambrian basement complex rocks of western Nigeria and on the east by the Abakaliki Anticlinorium. In this work attempt were made to study the recent or quaternary sediments of the Anambra basin using granulometric and geochemical methods in other to determine certain characteristics such as the depositional environment, grain size, and inorganic geochemistry.

\section{LOCATION}

The studied samples of the Quaternary sediments of the Anambra Basin were taken from the bank of the River Niger and sandbars on the River Niger as well as the Nkisi river mouth bar, all at Onitsha end of the Anambra basin. The study area lies between latitudes $6^{0} 09^{\prime} 00^{\prime \prime} \mathrm{N}$ and $6^{0} 11^{\prime} 24^{\prime \prime} \mathrm{Nand}$ longitudes $6^{0} 45^{\prime} 42^{\prime \prime} \mathrm{E}$ and $6^{0} 47^{\prime} 24^{\prime \prime} \mathrm{E}$, in Onitsha, Anambra state.

\section{REGIONAL GEOLOGY}

Anambra basin is located in the southeastern part of Nigeria. Anambra basin is bounded to the north by bida basin and northern Nigeria massif, to the east by benue trough, to the west by west African massif and to the south by Niger delta complex. The basin is a cretaceous basin having almost a roughly triangular shape with a total sediment thickness of about $9 \mathrm{~km}$, covers an area of about $40,000 \mathrm{~km}^{2}$. Anambra basin is characterized by enormous lithologic heterogeneity in both lateral and vertical extensions derived from a range of paleoenvironmental settings [2].

Anambra basin is a structural depression and is of the intracratonic basin in Nigeria, whose origin is related to

\footnotetext{
* Corresponding author, tel: $+234-803-486-1080$
} 
the separation of Africa from South America and the opening of South Atlantic Ocean [3]. According to Akaegbogbi [2], the sedimentation history in the lower Benue trough is related to the evolution of Anambra basin depression in Abakaliki domain. The evolutionary trend is patterned by shifting of depocenters.

The initial area of important sedimentation in the subsidence was located in the Abakaliki trough, which was active from Aptian to Santonian. The Anambra basin became an active depocenter after the Santonian tectonic event [4]. Gravity studies reveal appreciable thickness of the pre Santonian sediments, overlying the basement and reconfirm the subdivision of the basin into two sub basins by the Nsukka high [5]. The sequence of depositional events demonstrates a progressive deepening of the Anambra basin, from lower coastal plain and shoreline deltas to shoreline and shallow marine deposits.

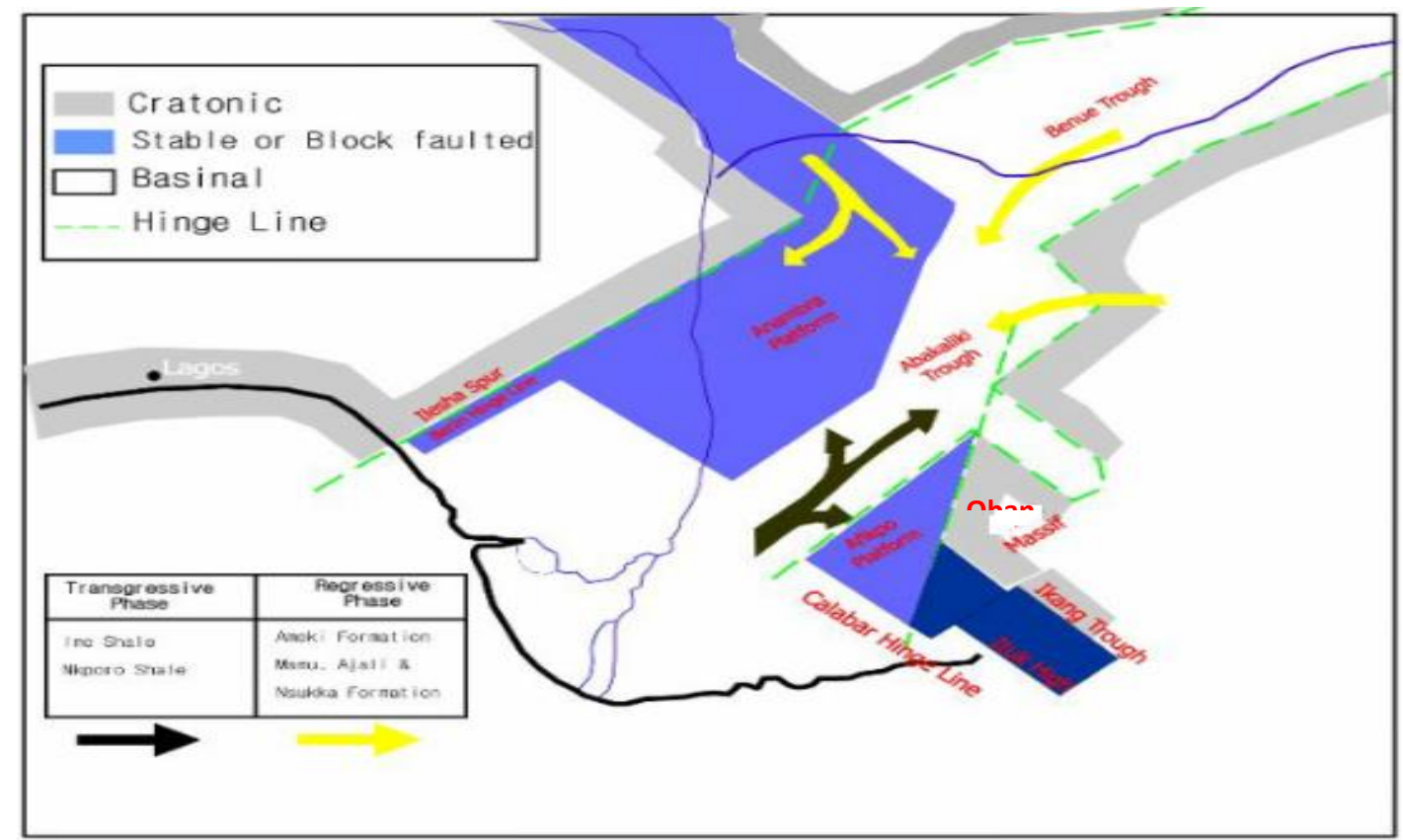

Fig. 1: Tectonic map of Southern-Eastern Nigeria showing the Anambra Basin (Adapted from Murat [1]).

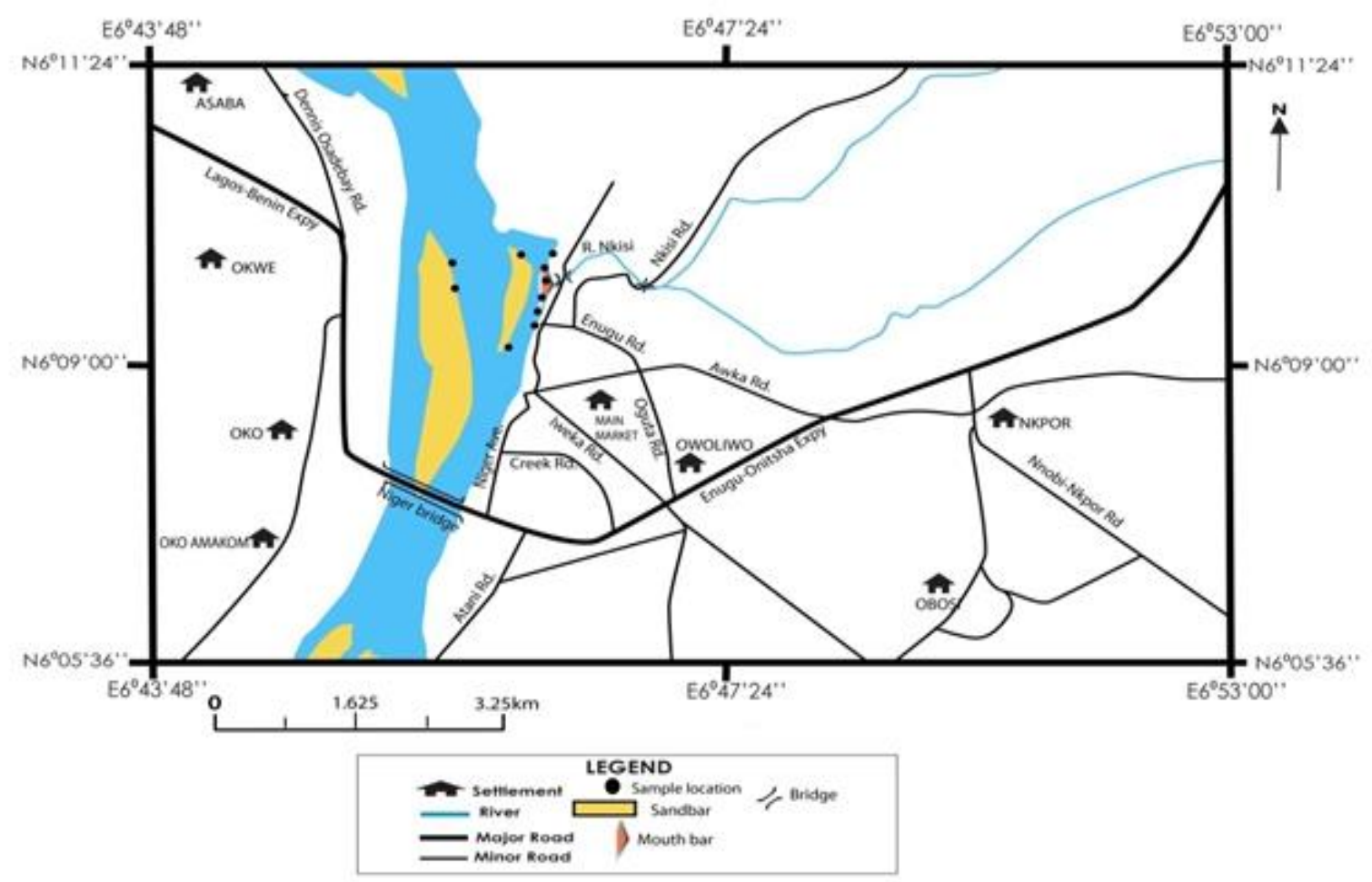

Fig. 2: Map of Onitsha and environs showing the sampled points. 


\section{MATERIALS AND METHODS}

A total of Ten samples were collected, Four of the samples were collected at the bank of river Niger $10 \mathrm{~m}$ apart, while two samples were collected at the mouth bar where river Nkisi enters the River Niger, a distance of about $20-45 \mathrm{mfrom}$ the market in the area, while four samples were collected from sand bars located in the river Niger with an approx distance of 150-400m apart. Each of the samples were put in a recommended sample bag and labeled. Most of the samples were not dry because they were collected from the river and oven drying was done.

Atomic Absorption Spectrophotometry was used to determine the major oxides. The double acid extraction was used to determine the contents of $\mathrm{SiO}_{2}, \mathrm{MnO}, \mathrm{MgO}$, $\mathrm{K}_{2} \mathrm{O}, \mathrm{Fe}_{2} \mathrm{O}_{3}, \mathrm{Na}_{2} \mathrm{O}, \mathrm{CaO}_{2}, \mathrm{TiO}_{2}$ and $\mathrm{Al} 203$ in the soil samples. Grain size analysis was also done using the sieving technique. Results were plotted on cumulative graphs from which interpretations were done.

\section{RESULTS AND DISCUSSION}

Table 1 shows the analytical results of the geochemical percentages of oxides in each sample, the samples were collected at different locations. The samples of each location were collected at a depth of $10-20 \mathrm{~cm}$.

The $\mathrm{SiO}_{2}$ contents range from 27.29 to $37.84 \%$ with an average of $33.45 \%$. The Alumina $\left(\mathrm{Al}_{2} \mathrm{O}_{3}\right)$ contents from ranges from 8.64 to $13.86 \%$ with an average of $10.23, \mathrm{Na}_{2} \mathrm{O}$ ranges from 10.43 to $15.88 \%$ with an average of $12.47, \mathrm{Fe}_{2} \mathrm{O}_{3}$ ranges from 5.47 to 9.42 with an average of $7.23, \mathrm{TiO}_{2}$ ranges from 0.21 to 0.68 with an average of $0.41, \mathrm{MgO}$ ranges from 5.05 to 9.82 with an average of $7.95, \mathrm{~K}_{2} \mathrm{O}$ ranges from 14.31 to $19.31 \%$ with an average of 16.78 , whereas $\mathrm{CaO}, \mathrm{MnO}$ shows relatively lower values ranging, between 7.47 to
$11.42 \%$ and 0.93 to 2.04 , with averages of 9.46 and 1.87. From the analysis the soil samples are relatively rich in $\mathrm{SiO}_{2}$

\section{CONTINENTAL SHELF SEDIMENTS AND SAND BARS}

\subsection{Continental Sediments}

The continental shelves are covered by terrigenous sediments; that is, those derived from erosion of the continents. However, little of the sediment is from current rivers; some $60-70 \%$ of the sediment on the world's shelves is relict sediment, deposited during the last ice age, when sea level was 100-120 m lower than it is now. Sediments usually become increasingly fine with distance from the coast; sand is limited to shallow, wave-agitated waters, while silt and clays are deposited in quieter, deep water far offshore. These shelf sediments accumulate at an average rate of $30 \mathrm{~cm} / 1000$ years, with a range from $15-40 \mathrm{~cm}$. Though slow by human standards, this rate is much faster than that for deep-sea pelagic sediments. Grain size decreases with distance from the shore, continental shelf is characterised by medium to coarse grain sands.

\subsection{Sand Bar Sediments}

Sand bars are morphological features predominantly parallel to the shoreline as in the study area, formed in shallow waters as a response to the action of hydrodynamic variables. They are typical of many sandy beaches around the world, particularly those characterized by unconsolidated sediments of sand fractions with average grain size between 0.1 and 0.5 $\mathrm{mm}$. Sand bars are characterized by fine to medium grain sands.

Table 1: Result of geochemical analysis

\begin{tabular}{ccccccccccc}
\hline & & $\mathrm{SiO}_{2}$ & $\mathrm{TiO}_{2}$ & $\mathrm{Al}_{2} \mathrm{O}_{3}$ & $\mathrm{MnO}$ & $\mathrm{MgO}$ & $\mathrm{CaO}$ & $\mathrm{Na}_{2} \mathrm{O}$ & $\mathrm{K}_{2} \mathrm{O}$ & $\mathrm{Fe}_{2} \mathrm{O}_{3}$ \\
\hline $\mathrm{S} / \mathrm{NO}$ & SAMPLE NO & $\%$ & $\%$ & $\%$ & $\%$ & $\%$ & $\%$ & $\%$ & $\%$ & $\%$ \\
1 & $\mathrm{AB} / 10 / 11 / 01 / \mathrm{SB}$ & 35.86 & 0.64 & 11.92 & 1.52 & 5.85 & 7.47 & 10.43 & 17.09 & 5.47 \\
2 & $\mathrm{AB} / 10 / 11 / 03 / \mathrm{SB}$ & 33.76 & 0.64 & 10.78 & 0.98 & 5.57 & 8.11 & 15.66 & 19.31 & 6.11 \\
3 & $\mathrm{AB} / 10 / 11 / 05 / \mathrm{SB}$ & 39.05 & 0.21 & 8.64 & 2.11 & 7.96 & 10.08 & 11.32 & 14.87 & 8.08 \\
4 & $\mathrm{AB} / 10 / 11 / 06 / \mathrm{SB}$ & 37.84 & 0.48 & 7.77 & 1.32 & 5.05 & 8.53 & 13.52 & 14.31 & 6.53 \\
5 & $\mathrm{AB} / 10 / 11 / 04 / \mathrm{CS}$ & 27.29 & 0.37 & 13.86 & 1.11 & 9.82 & 10.05 & 13.33 & 15.68 & 8.05 \\
6 & $\mathrm{AB} / 10 / 11 / 07 / \mathrm{CS}$ & 28.43 & 0.33 & 10.45 & 1.46 & 7.58 & 9.47 & 15.88 & 17.21 & 7.47 \\
7 & $\mathrm{AB} / 10 / 11 / 08 / \mathrm{CS}$ & 29.92 & 0.51 & 8.72 & 0.93 & 8.43 & 10.42 & 13.02 & 18.47 & 8.42 \\
8 & $\mathrm{AB} / 10 / 11 / 10 / \mathrm{CS}$ & 28.56 & 0.68 & 11.77 & 1.53 & 9.52 & 10.11 & 13.57 & 16.26 & 8.11 \\
9 & $\mathrm{AB} / 10 / 11 / 02 / \mathrm{MB}$ & 28.54 & 0.53 & 9.68 & 1.73 & 9.01 & 11.42 & 14.97 & 17.08 & 9.42 \\
10 & $\mathrm{AB} / 10 / 11 / 09 / \mathrm{MB}$ & 33.69 & 0.39 & 8.89 & 2.04 & 6.66 & 8.57 & 14.36 & 16.58 & 6.57 \\
& $\mathrm{AVERAGE}$ & 33.45 & 0.41 & 10.23 & 1.87 & 7.95 & 9.46 & 12.47 & 16.78 & 7.23 \\
\hline
\end{tabular}

$\mathrm{N}, \mathrm{B}: \mathrm{SB}=$ Sand bar, $\mathrm{CS}=$ Continental shelf, $\mathrm{MB}=$ Mouth bars, $\mathrm{AB}=$ Anambra Basin 


\section{COMPARISON BETWEEN SAND BARS AND CONTINENTAL SHELF SEDIMENT}

From the studied samples, the sand bar sediments are characterized by fine to medium grain sands, while the continental sediments have grain sizes range of medium to coarse sands. The Sand bar sediments have been subjected to longer transportation compared to continental sediments which result in better sorting. Sand bar sediments have also been exposed to more intense weathering compared to continental sediments which is responsible for the higher percentage of $\mathrm{SiO}_{2}$ in the sand bars, which can be observed in table 1; sample no. $A B / 10 / 11 / 05 / S B$ and $A B / 10 / 11 / 06 / S B$. Sand bars sediments are composed of cleaner sands compared to continental shelf sediments, this is as a result of long distance of transportation.

The mouth bars sediments share characteristics of both sand bars and continental shelf sediments, its grain size ranges from fine to coarse, which could be seen in $\mathrm{AB} / 10 / 11 / 02 / \mathrm{MB}$ and $\mathrm{AB} / 10 / 11 / 09 / \mathrm{MB}$ (See Table 3 ). Its chemistry could be associated to that of the sand bar or continental shelf sediments depending on the water body (river, stream) in which it dwells and that in which it comes in contact with..

\section{GRAIN SIZE RESULT}

Cumulative frequency curves were plotted from the percent cumulative weight retained in each sieves against sieve sizes in phi scale $(\varnothing)$ on an arithmetic log paper. The following percentiles were obtained $\emptyset 95$, $\emptyset 84, \varnothing 75, \varnothing 50, \emptyset 25, \emptyset 16$ and $\varnothing 5$ which was used to compute and calculate the following statistical parameters which include, Graphic mean size, inclusive graphic standard deviation, inclusive graphic skewness, and graphic kurtosis from formula proposed by Folk, et al [6]. Interpretations were made and tabulated.

Table 2 (a): Results obtained from grain size analysis

\begin{tabular}{|c|c|c|c|c|c|c|c|}
\hline \multicolumn{2}{|c|}{ Particle Size } & \multicolumn{3}{|c|}{ SAMPLE 1, (SANDBAR) AB/10/11/01/SB } & \multicolumn{3}{|c|}{ SAMPLE 2 (SANDBAR) AB/10/11/03/SB } \\
\hline $\mathrm{Mm}$ & $\theta$ & $\begin{array}{c}\mathrm{Wt} \\
\text { Retained }\end{array}$ & $\begin{array}{c}\% \mathrm{Wt} \\
\text { Retained }\end{array}$ & $\begin{array}{c}\% \mathrm{C} . \mathrm{Wt} \\
\text { Retained }\end{array}$ & $\begin{array}{c}\% \mathrm{Wt} \\
\text { Retained }\end{array}$ & $\begin{array}{c}\text { Wt } \\
\text { Retained }\end{array}$ & $\begin{array}{c}\% \text { C.Wt } \\
\text { Retained }\end{array}$ \\
\hline 1.700 & -0.77 & 0.76 & 0.69 & 0.69 & 1.85 & 1.05 & 1.05 \\
\hline 0.850 & 0.2 & 8.69 & 7.83 & 8.52 & 21.63 & 19.22 & 20.21 \\
\hline 0.500 & 1 & 6.76 & 6.15 & 14.67 & 17.94 & 15.94 & 36.21 \\
\hline 0.300 & 1.74 & 6.48 & 5.90 & 20.57 & 8.99 & 7.99 & 44.2 \\
\hline 0.212 & 2.24 & 5.33 & 4.85 & 25.42 & 41.32 & 36.72 & 80.92 \\
\hline 0.075 & 3.74 & 69.81 & 63.53 & 89.23 & 4.97 & 4.42 & 85.34 \\
\hline 0.063 & 3.99 & 3.1 & 2.82 & 92.05 & 3.01 & 2.68 & 88.02 \\
\hline Pan $>$ & 3.99 & 8.95 & 8.15 & 100.2 & 12.81 & 11.38 & 99.4 \\
\hline \multicolumn{2}{|c|}{$\begin{array}{c}\text { Summation of wt } \\
\text { Retained }\end{array}$} & 109.88 & & & 112.52 & & \\
\hline
\end{tabular}

Table 2: (b) Result obtained from grain size analysis

\begin{tabular}{|c|c|c|c|c|c|c|c|}
\hline \multicolumn{2}{|c|}{ Particle Size } & \multicolumn{2}{|c|}{$\begin{array}{c}\text { SAMPLE 7(CONTINENTAL SHELF) } \\
\text { AB } / 10 / 11 / 08 / \mathrm{CS} \\
\end{array}$} & \multicolumn{4}{|c|}{$\begin{array}{c}\text { SAMPLE 8(CONTINENTAL SHELF) } \\
\text { AB } / 10 / 11 / 04 / C S\end{array}$} \\
\hline $\mathrm{Mm}$ & $\theta$ & Wt Retained & $\%$ Wt Retained & $\begin{array}{c}\% \text { C.Wt } \\
\text { Retained }\end{array}$ & Wt Retained & $\begin{array}{c}\% \mathrm{Wt} \\
\text { Retained }\end{array}$ & $\begin{array}{l}\text { \% C.Wt } \\
\text { Retained }\end{array}$ \\
\hline 1.700 & -0.77 & 17.74 & 17.22 & 17.22 & 17.55 & 15.72 & 15.72 \\
\hline 0.850 & 0.2 & 2.16 & 2.10 & 19.32 & 16.81 & 3.47 & 19.19 \\
\hline 0.500 & 1 & 16.31 & 16.32 & 35.64 & 0.33 & 15.76 & 34.95 \\
\hline 0.300 & 1.74 & 7.89 & 7.66 & 43.3 & 1.59 & 27.45 & 62.4 \\
\hline 0.212 & 2.24 & 2.63 & 2.55 & 45.85 & 2.16 & 7.74 & 70.14 \\
\hline 0.075 & 3.74 & 21.71 & 21.08 & 66.93 & 12.64 & 11.80 & 81.94 \\
\hline 0.063 & 3.99 & 8.66 & 8.41 & 75.34 & 7.21 & 3.50 & 85.44 \\
\hline $\operatorname{Pan}>$ & 3.99 & 26.08 & 25.32 & 100.66 & 10.88 & 13.35 & 98.79 \\
\hline \multicolumn{2}{|c|}{$\begin{array}{l}\text { Summation of wt } \\
\text { Retained }\end{array}$} & 103.18 & & & 69.17 & & \\
\hline
\end{tabular}


The mean grain size ranges from 0.8 to 2.9 , which corresponds to Coarse to fine grain sands but averagely (2.03) which is fine grained, Standard deviation ranges from 0.28 to 1.21 which ranges from very well sorted to poorly sorted, but averagely 0.74 which is moderately sorted. The skewness ranges from -0.34 to 1.13 ie strongly coarse skewed to strongly fine skewed but averagely near symmetrical. The kurtosis ranges from 0.42 to 1.25 ie very platykurtic to leptokurtic but averagely 1.4 which is leptokurtic.

The fine grained sediments dominates the studied samples as observed from the grain analysis and graphic mean, and field relationships suggests that the unit was deposited in an environment where there was low to moderate tidal or wave action i.e where low energy regime favoured deposition of fine - medium size sediments..

Table 2 (c): Results obtained from grain size analysis

\begin{tabular}{|c|c|c|c|c|c|c|c|c|}
\hline \multicolumn{2}{|c|}{ Particle Size } & \multicolumn{4}{|c|}{$\begin{array}{c}\text { SAMPLE } 9 \text { (MOUTH BAR) } \\
\text { AB/10/11/02/MB } \\
\end{array}$} & \multicolumn{3}{|c|}{$\begin{array}{c}\text { SAMPLE } 10 \text { (MOUTH BAR) } \\
\text { AB/10/11/09/MB } \\
\end{array}$} \\
\hline $\mathrm{Mm}$ & $\theta$ & $\begin{array}{l}\text { Wt } \\
\text { Retained }\end{array}$ & $\begin{array}{l}\% \\
\text { Retained } \\
\end{array}$ & Wt & $\begin{array}{l}\text { \% C.Wt } \\
\text { Retained }\end{array}$ & $\begin{array}{l}\text { Wt } \\
\text { Retained } \\
\end{array}$ & $\begin{array}{ll}\% & \mathrm{Wt} \\
\text { Retained } & \\
\end{array}$ & $\begin{array}{ll}\% & \text { C.Wt } \\
\text { Retained } & \\
\end{array}$ \\
\hline 1.700 & -0.77 & 17.55 & 25.37 & & 25.37 & 18.11 & 16.59 & 16.59 \\
\hline 0.850 & 0.2 & 16.81 & 24.30 & & 49.67 & 4.02 & 3.68 & 20.27 \\
\hline 0.500 & 1 & 0.33 & 0.48 & & 50.15 & 18.71 & 17.14 & 37.41 \\
\hline 0.300 & 1.74 & 1.59 & 2.30 & & 52.45 & 1.09 & 1.00 & 38.41 \\
\hline 0.212 & 2.24 & 2.16 & 3.12 & & 55.57 & 22.89 & 20.97 & 59.38 \\
\hline 0.075 & 3.74 & 12.64 & 18.27 & & 73.84 & 40.03 & 36.68 & 96.06 \\
\hline 0.063 & 3.99 & 7.21 & 10.42 & & 84.26 & 2.77 & 2.54 & 98.6 \\
\hline $\operatorname{Pan}>$ & 3.99 & 10.88 & 15.73 & & 99.99 & 1.52 & 1.39 & 99.99 \\
\hline $\begin{array}{l}\text { Summ } \\
\text { Retain }\end{array}$ & of & 69.17 & & & & 109.14 & & \\
\hline
\end{tabular}

Table 3: Statistical parameters obtained from calculation using Folk and Ward [6] and their interpretation

\begin{tabular}{|c|c|c|c|c|c|}
\hline Sample No & $\begin{array}{l}\text { Graphic } \\
\text { Mean Size }\end{array}$ & $\begin{array}{l}\text { Standard } \\
\text { Deviation }\end{array}$ & $\begin{array}{c}\text { Graphic } \\
\text { Skewness }\end{array}$ & $\begin{array}{l}\text { Graphic } \\
\text { Kurtosis }\end{array}$ & Interpretation \\
\hline $\mathrm{AB} / 10 / 11 / 01 / \mathrm{SB}$ & 2.5 & 0.38 & -1.0 & 1.6 & $\begin{array}{l}\text { Fine grained, well sorted, near } \\
\text { symmetrical and very leptokurtic }\end{array}$ \\
\hline $\mathrm{AB} / 10 / 11 / 02 / \mathrm{MB}$ & 0.8 & 1 & 0.35 & 0.67 & $\begin{array}{l}\text { Coarse grained, moderately sorted, } \\
\text { strongly fine skewed and very } \\
\text { platykurtic }\end{array}$ \\
\hline $\mathrm{AB} / 10 / 11 / 03 / \mathrm{SB}$ & 2.7 & 0.28 & 1.13 & 1.08 & $\begin{array}{l}\text { Fine grained, well sorted, strongly } \\
\text { fine skewed mesokurtic }\end{array}$ \\
\hline $\mathrm{AB} / 10 / 11 / 04 / \mathrm{CS}$ & 1.76 & 0.62 & -1.02 & 0.56 & $\begin{array}{l}\text { medium grained, moderately } \\
\text { sorted, strongly coarsely skewed } \\
\text { and very platykurtic }\end{array}$ \\
\hline $\mathrm{AB} / 10 / 11 / 05 / \mathrm{SB}$ & 2.9 & 0.36 & 0.13 & 1.25 & $\begin{array}{l}\text { Fine grain,well sorted, fine skewed } \\
\text { and leptokurtic }\end{array}$ \\
\hline $\mathrm{AB} / 10 / 11 / 06 / \mathrm{SB}$ & 2.6 & 0.71 & 0.16 & 0.81 & $\begin{array}{l}\text { Fine grained, moderately well } \\
\text { sorted, fine skewed and platykurtic }\end{array}$ \\
\hline $\mathrm{AB} / 10 / 11 / 07 / \mathrm{CS}$ & 0.92 & 0.93 & -0.34 & 0.65 & $\begin{array}{l}\text { Coarse grained, moderately sorted, } \\
\text { strongly coarsely skewed and very } \\
\text { platykurtic }\end{array}$ \\
\hline $\mathrm{AB} / 10 / 11 / 08 / \mathrm{CS}$ & 1.9 & 1.1 & 0.88 & 0.75 & $\begin{array}{l}\text { Medium grained, poorly sorted, near } \\
\text { symmetrical and platykurtic }\end{array}$ \\
\hline $\mathrm{AB} / 10 / 11 / 09 / \mathrm{MB}$ & 2.48 & 0.77 & -0.46 & 0.6 & $\begin{array}{l}\text { fine grained, moderately sorted, } \\
\text { strongly coarsed skewed and very } \\
\text { platykurtic }\end{array}$ \\
\hline $\mathrm{AB} / 10 / 11 / 10 / \mathrm{CS}$ & 1.8 & 1.21 & 0.36 & 0.58 & $\begin{array}{l}\text { Medium grained, poorly sorted, } \\
\text { strongly fine skewed and platykurtic }\end{array}$ \\
\hline AVERAGE & 2.04 & 0.74 & -0.04 & 1.4 & \\
\hline
\end{tabular}


The result from the analysis reveals a poorly sorted sediments. The kurtosis revealed leptokurtic to platykurtic which suggest that the sediments were sourced from more than one source which is similar to the observation made by Akaegbobi and Boboye [7] about the Anambra Basin sediments

\section{CONCLUSION}

The study of these quaternary sediments from the Anambra Basin revealed a greater proportion of $\mathrm{SiO}_{2}$ which means that they have been subjected to intensive weathering. The analysis between the sand bars, mouth bars and continental sediments revealed inherent, textural characteristics, differences between them which are pointers to the paleo-environment and conditions of deposition as well as the provenance.

\section{REFERENCES}

[1] Murat, R. C.. Stratigraphy and Paleogeography of the Cretaceous and Lower Tertiary in Southern Nigeria. African Geol. University of Ibadan Press, 1972, pp. 251-268
[2] Akaegbobi I. M., "Sequence Stratigraphy of Anambra Basin", Journal of African Earth Sciences. Vol. 42, 394-406, 2005.

[3] Ofoegbu, C. O. A review of the Geology of the Benue Trough of Nigeria, Jour. Africa Earth Sci. 3, $283-291,1985$.

[4] Reyment, R. A. "Aspect of the Geology of Nigeria", lbadan: University Press, p. 133-145, 1965.

[5] Reyment, R. A.. "Review of Nigerian Cretaceous Cenonozoic Stratigraphy", Jour. Min. Geol. Vol. 2, p. 61-80, 1965.

[6] Folk, R. l and Ward, W. C. "Brazos River bar: a study of the significance of grain size parameters", Journal of Sedimentary Petrology, 27:3-26, 1957.

[7] Akaegbobi, I. M and Boboye, A. O. "Textural Structural Features and Micrfossil Assemblage Relationship as a delineating Criteria for the Stratigraphic Boundary between Mamu Formation and Nkporo Shale within the Anambra Basin, Nigeria", NAPE Bulletin, 14 (2),p.193-207, 1999. 